\title{
An Index Approach to Metallic Pollution in Groundwater Sources of South Region of Pemba Island
}

\author{
Abdul A. J. Mohamed ${ }^{1, ~ *, ~ I b r a h i m ~ A b d u l ~ R a h m a n ², ~ L e e ~ H . ~ L i m ², ~ S a r a ~ A . ~ K h a m i s ~}{ }^{1}$, Haji Mwevura1, \\ Kombo H. Mbwana ${ }^{1}$
}

${ }^{1}$ Department of Natural Sciences, the State University of Zanzibar, Zanzibar, Tanzania

${ }^{2}$ Faculty of Science (FOS), Universiti Brunei Darussalam JalanTungku, Brunei Darussalam, Brunei

\section{Email address:}

jumabdull@yahoo.com (A. A. J. Mohamed)

\section{To cite this article:}

Abdul A. J. Mohamed, Ibrahim Abdul Rahman, Lee H. Lim, Sara A. Khamis, Haji Mwevura, Kombo H. Mbwana. An Index Approach to Metallic Pollution in Groundwater Sources of South Region of Pemba Island. Science Journal of Analytical Chemistry.

Vol. 4, No. 2, 2016, pp. 12-21. doi: 10.11648/j.sjac.20160402.11

\begin{abstract}
The South Region of Pemba is one of the two Regions in Pemba Island. Residents within the region depend on groundwater as the main water source for the domestic and other social purposes. This study was conducted to assess the quality of drinking water in different areas of South region of Pemba. In order to evaluate the quality of groundwater in the study area, 17 groundwater samples were collected and analyzed for different physico-chemical parameters. In each water sample, four physicochemical parameters were analyzed, namely, electrical conductivity (EC), total dissolved solids (TDS), $\mathrm{pH}$, and turbidity. For the case of metals, eleven metals, namely, $\mathrm{Cd}, \mathrm{Co}, \mathrm{Cu}, \mathrm{Cr}$ (III), $\mathrm{Li}, \mathrm{Fe}, \mathrm{Mg}, \mathrm{Ni}, \mathrm{Pb}, \mathrm{Sr}$, and $\mathrm{Zn}$ were analyzed using standard procedures. The dataobtained were then compared with the available WHO and or USEPA drinking water standards. All the samples had EC and TDS within the recommended limits, while $53 \%$ and $29 \%$ of the samples had higher turbidity levels and lower $\mathrm{pH}$, respectively than the WHO recommended guidelines. All the samples contained $\mathrm{Co}, \mathrm{Cu}$, $\mathrm{Fe}, \mathrm{Mg}, \mathrm{Ni}, \mathrm{Pb}$, and $\mathrm{Zn}$ within the maximum admissible limits. According to heavy metal pollution index (HPI), degree of contamination (Cd), and heavy metal evaluation index (HEI), only one area (Mgonanje-1) showed alarming risks. In most water samples, the ratio of concentrations of $\mathrm{Li}$ to $\mathrm{Ni}$ was greater than 1, while all $\mathrm{Sr}$ to $\mathrm{Mg}$ ratios were less than 1 . Generally, the values of the analyzed physico-chemical parameters were within the recommended maximum admissible limits. However, the study recommends the stakeholders and other responsible authorities to take appropriate and corrective measures for the water sources located at the Mgonanje area.
\end{abstract}

Keywords: Mgonanje, Alarming Risks, Li/Ni Ratio, Sr/Mg Ratio, HPI, HEI, Pemba Island

\section{Introduction}

The significance of water quality in human health and welfare attracts a great deal of interest and attention in the world. Access to adequate and safe water is essential for human survival, and is one among the fundamental human rights. Concerning public health, limited access to safe water undermines other public sectors such as public health, for instance communicable diseases. The provision of potable drinking water has been given priority in all national and international working documents.

Groundwater is a precious natural resource that is essential and fundamental for human health, socio-economic development, and functioning of ecosystems [1,2]. Water supply sector plays a major role directly or indirectly to the economy growth and social well being. The inadequate access to clean water is directly linked with the lack of basic sanitation [3]. Nevertheless, ground water can be polluted through contaminants originating from both natural and anthropogenic sources; and once water source is polluted, process to revamp the situation becomes very difficult [4]. The quality of groundwater is affected by natural and anthropogenic activities or factors. Numerous types of human activities including residential, municipal, commercial, industrial, and agricultural activities can all affect groundwater quality [5].

It is estimated that about 1.1 billion people globally drink unsafe water and the vast majority of diarrheal disease in the 
world $(88 \%)$ is attributable to unsafe water, sanitation and hygiene [6]. Microbial contamination is the most widespread form of groundwater contamination. It carries major health risks especially in developing world [7]. The quality of water is a crucial concern for humankind and development, since it is directly linked with human welfare [8].

Underground aquifers are the main source of domestic water in Zanzibar, but the quality of the water sources in different areas is at alarming risk due to deteriorating environmental conditions [9, 10]. In Pemba Island, large portion of the population is dependent on groundwater as a major source of water supply to meet domestic and other social purposes. Most of the water sources are hand-dug wells, and they form the major sources of portable water to nearby villages. Some of the wells are located within the vicinity of town municipality, while other sources are in remote areas.

Anthropogenic release of pollutants to the ground is a potential source of groundwater contamination. This is because; pollutants released to the ground find their way down to the soil profiles into the groundwater aquifers. Such type of contamination is very common in water sources located within unplanned settlements, which are characterized with dense population and poor or no sanitation facilities.

The levels of heavy metals and toxic contaminants either in their organic or inorganic form, have been continuously increasing in various areas of world [11]. Low recharge rate coupled with over-exploitation of groundwater, hydrogeochemical characteristics of the area can result in shaping more pollutants infiltration and rapid deterioration of water quality.

Furthermore, it is documented that the polluted water affects the human health, soil nutrients, livestock, biomass and environment in certain areas [12]. The infiltrations of noxious impurities from various sources such as municipal sewerage, agricultural and domestic effluents are among the key factors, which cause the deterioration of portable water quality [13].

When some metals are present in human body at certain dose, they can cause detrimental health effects. As an example, lead $(\mathrm{Pb})$, when ingested at a certain level can lead to human health consequences, such as, vomiting, loss of appetite, anemia, intestinal colic, headaches, double vision, mental disturbance, anxiety, convulsions, coma, muscular weakness, loss of memory, and damage of brain, liver and kidney [14]. Cadmium (Cd) is a non-essential element for living organisms and has very high mobility in soil-plant systems, with tendency to adversely affect both human health and the functioning of ecosystems [15]. While the shortage of iron causes disease called "anemia" and extended consumption of drinking water with high concentration of iron may lead to liver disease called as haermosiderosis [16].

Other metals such as; Mn, As, Ti, Cr, V, Co, Cu, Fe, Ni, and $\mathrm{Zn}$ and their compounds have been found to be initiators or promoters of carcinogenic activity in animals. Furthermore, $\mathrm{Al}, \mathrm{Hg} \mathrm{Be}, \mathrm{Sb}, \mathrm{Ni}, \mathrm{Co}$ and $\mathrm{Cd}$ can cause adverse reproductive/fertility problems [17].

There are few studies on status of water quality in Zanzibar, and majority of them give strong emphasis on microbial contamination, while physco-chemical contamination seems to be of little attention. This trend is based on the logic that microbial contamination has acute responses as compared to other categories. However, physico-chemical contamination is of equal importance, and its consequences can be linked to non-communicable diseases such as cancer. Recent studies on physico-chemical contamination carried out in Urban West Region of Zanzibar Island have indicated that large proportion of water samples contain various chemical species and some of which have carcinogenic effects $[9,10]$.

Natural groundwater contaminants and other unwanted constituents or impurities, can reach such a level that is detrimental for human life. Types, abundances, and concentrations of natural occurring impurities depend on the geological and hydrological conditions of the area. Nevertheless, soil microbial activities, the amount of falling precipitation and its $\mathrm{pH}$ can play significant role on the transport and fate of contaminants in to groundwater via different soil zones. As recharge water moves down the soil profile it may pick up a wide range of chemical species, such as magnesium, calcium, and chlorides. Thus, quality of the recharge water may also be subjected to considerable variations.

The purpose of this study is to assess the quality of groundwater sources used in South Region of Pemba Island with respect to selected physico-chemical parameters. An estimate was donefor the risk potential due to metal pollution in analyzed groundwater. Three indices namely heavymetal pollution index (HPI), hazard index (HI), and degree of contamination index $\left(\mathrm{C}_{\mathrm{d}}\right)$ were taken into consideration in estimating the metal pollution in groundwater.

\section{Materials and Methods}

In this study, water samples were collected from community water sources in the South region of Pemba Island. The collection of water samples was made in November, 2014, whereby a total of seventeen water samples were collected in different wells. The positions of the wells were marked using Global Positioning System (GPS) as presented in figure 1. The samples were collected in precleaned polyethylene bottles that were rinsed with the water sample of the particular location. Before analysis, the samples were subsequently stored at $4^{\circ} \mathrm{C}$ for short a time as possible to minimize changes of the physicochemical characteristics of the metals [18].

The collected samples were then transported and stored in laboratory for analysis. Handling of the samples at different stages was in accordance with the protocol given in the standard EPA method 200.7. 


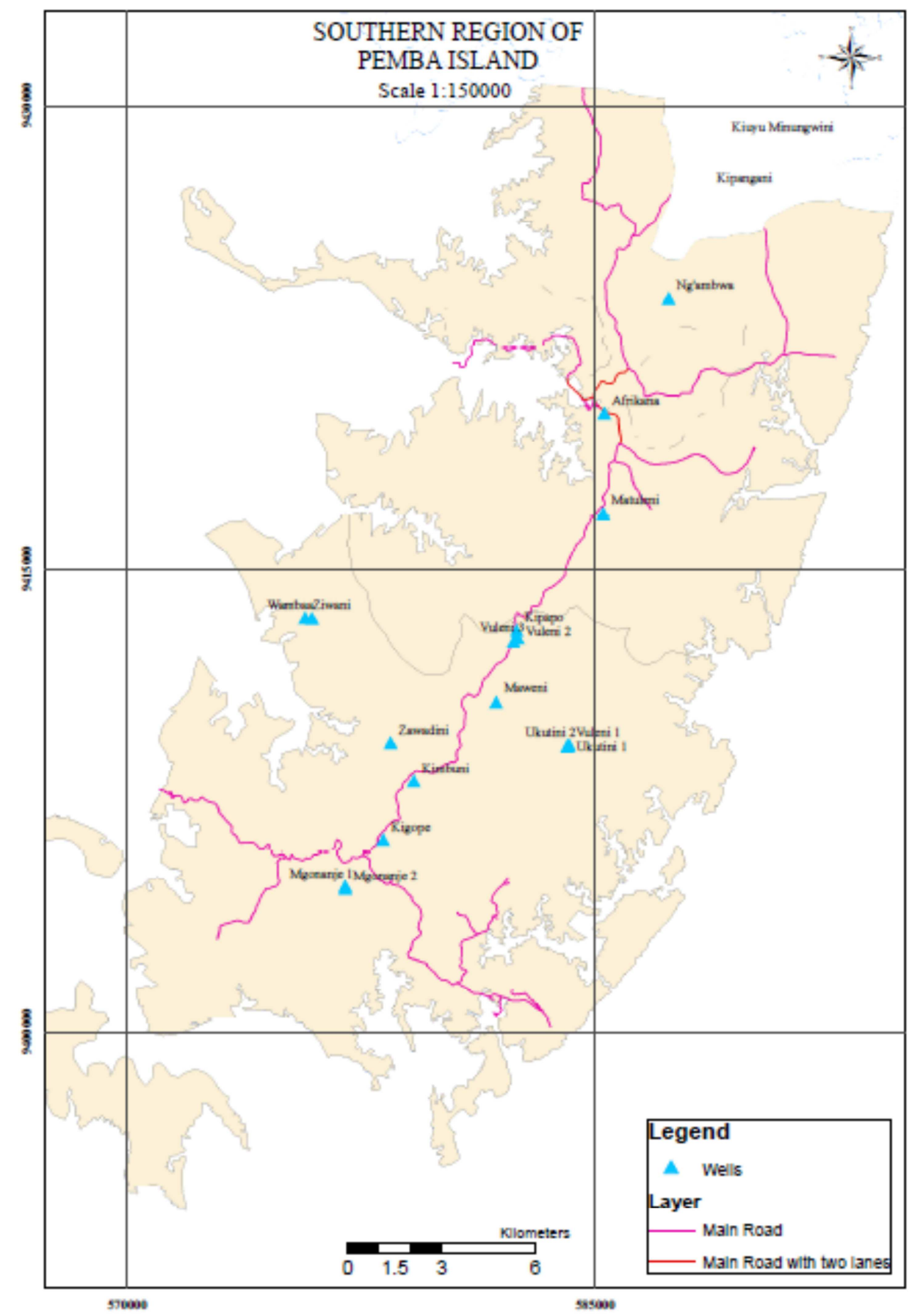

Figure 1. Location of the sampling areas in South Region of Pemba Island.

\subsection{Analysis of the Samples}

The $\mathrm{pH}, \mathrm{EC}$, turbidity and TDS were measured in situ using Hariba multi-parameter water quality meter Model U53G. An Inductively Coupled Plasma Optical Emission Spectroscopy (ICP-OES, Thermo Scientific iCAP 6000) method was used to determine concentrations of eleven metals which are, cadmium, lithium, strontium, magnesium, cobalt, nickel, lead, iron, chromium, zinc, and copper. Before the metal analysis, ICP-OES was calibrated using standard manufactured stock solution.

\subsection{Reagents}

All the chemicals used for the analytical determination were ultrapure compounds. Water for standard preparations was ultrapure water from Fisher/Barnstead with resistivity of $17.9-18.3 \mathrm{M} \Omega-\mathrm{cm}$. The standard multi-elements stock solutionswere purchased from Inorganic Ventures, Merck (Darmstadt, Germany). The standard multi-elements stock solutions containing $1000 \mathrm{ppm}$, and the elements contained are such as; $\mathrm{Cu}, \mathrm{Ni}, \mathrm{Pb}, \mathrm{Na}, \mathrm{Ca}, \mathrm{As}, \mathrm{Li}, \mathrm{Mg}, \mathrm{Mn}, \mathrm{Sr}$, and $\mathrm{Mn}$. 


\subsection{Data Analysis}

Descriptive statistics including univariate and multivariate statistical methods of analysis were also used in the study. The software SPSS 16.0 was used for statistical analysis. The correlation-matrix, which is based on the Pearson's correlation coefficient, was utilized for displaying relationships between variables.

\subsection{Pollution Evaluation Indices}

Nature of the examined parameters was selected based on, firstly, the consequences of the anthropogenic activities, agriculture in particular, and secondly, the location of the water sources (up the hill or down the hill). In general, pollution indices are applied to give an estimate of the quality of the water under consideration. In this study, heavy metal pollution index (HPI), heavy metal evaluation index (HEI) and the degree of contamination $\left(\mathrm{C}_{\mathrm{d}}\right)$ were calculated for each water sample (Eq. 1-5). The values of these indices are presented on Figure A2.

The HPI and HEI methods provide an overall quality of the water with respect to heavy metals. The $C_{d}$ method, gives an estimate of the quality of water with respect to the degree of contamination using contamination factor. Therefore, the $\mathrm{C}_{\mathrm{d}}$ recapitulates the combined effects of a number of quality parameters regarded as unsafe to domestic water [19].

The indices evaluated in this study are; heavy metal pollution index (HPI) as proposed by [20]. $\mathrm{C}_{\mathrm{d}}$ also known as contamination index, which was developed by [21]. $C_{d}$ is also used as reference for estimating the extent of metal pollution [22]. Degree of contamination is classified in to three categories, namely, low $\left(C_{d}<1\right)$, medium $\left(C_{d}=1-3\right)$, and high $\left(\mathrm{C}_{\mathrm{d}}>1\right)$ [23]. Heavy metal evaluation index (HEI) depicts an overall quality of the water with respect to heavy metals [23].

$$
H P I=\sum_{i=1}^{n} W i Q i / \sum_{i=1}^{n} W i
$$

Where: Wi and Qi are unit weight and the sub-index of the $i^{\text {th }}$ parameter, respectively, and $n$ is the number of parameters considered. The sub-index (Qi) is calculated according to Eq. (2).

$$
\begin{gathered}
Q i=\sum_{i=1}^{n} \frac{|M i-I i|}{S i-I i} \times 100 \\
H E I=\sum_{i=1}^{n} \frac{H_{c}}{H_{\text {mac }}}
\end{gathered}
$$

Where: $\mathrm{H}_{\mathrm{c}}$ and $\mathrm{H}_{\mathrm{mac}}$ are monitored and maximum admissible concentration respectively.

$$
C_{d}=\sum_{i=1}^{n} C_{f_{i}}
$$

$\mathrm{C}_{\mathrm{fi}}$ is a subindex, which shows contamination factor and is calculated according to Eq. (5)

$$
C_{f i}=\frac{C M_{i}}{C S_{i}}-1
$$

$\mathrm{C}_{\mathrm{fi}}, \mathrm{CM}_{\mathrm{i}}$, and $\mathrm{CS}_{\mathrm{i}}$, are the contamination factor, analytical value, and upper permissible concentration for $i^{\text {th }}$ component respectively, while $\mathrm{n}$ denotes the 'normative value'.

\section{Results and Discussion}

The results on metal concentration and other physicchemical parameters are summarized in Table 1.

Table 1. Descriptive statistics showing the concentrations of the analyzed parameters.

\begin{tabular}{lllllll}
\hline Parameter & Unit & Min. Level & Max. Level & Site with Max. Level & MAL & Area with max. detected concentration \\
\hline $\mathrm{Cd}$ & $\mathrm{mgL}^{-1}$ & $<\mathrm{DL}$ & 31 & 14 & $0.003^{\mathrm{a}}$ & Mgonanje1 \\
$\mathrm{Co}$ & $\mathrm{mgL}^{-1}$ & $<\mathrm{DL}$ & 0.0005 & 4 & $0.1^{\mathrm{b}}$ & Ukutini1 \\
$\mathrm{Cr}(\mathrm{III})$ & $\mathrm{mgL}^{-1}$ & $<\mathrm{DL}$ & 0.0346 & 8 & $\mathrm{~N} / \mathrm{A}$ & Maweni \\
$\mathrm{Cu}$ & $\mathrm{mgL}^{-1}$ & $<\mathrm{DL}$ & 0.0612 & 1 & $1^{\mathrm{a}}$ & Afrikana \\
$\mathrm{Fe}$ & $\mathrm{mgL}^{-1}$ & $<\mathrm{DL}$ & 0.0057 & 14 & $0.2^{\mathrm{a}}$ & Mgonanje1 \\
$\mathrm{Li}$ & $\mathrm{mgL}^{-1}$ & 0.0162 & 0.0622 & 15 & $\mathrm{~N} / \mathrm{A}$ & Mgonanje2 \\
$\mathrm{Mg}$ & $\mathrm{mgL}^{-1}$ & 1.2 & 12.3 & 14 & $50^{\mathrm{a}}$ & Mgonanje1 \\
$\mathrm{Ni}$ & $\mathrm{mgL}^{-1}$ & 0.0029 & 10.11 & 14 & $0.02^{\mathrm{a}}$ & Mgonanje1 \\
$\mathrm{Pb}$ & $\mathrm{mgL}^{-1}$ & $<\mathrm{DL}$ & 0.0097 & 14 & $0.015^{\mathrm{a}}$ & Mgonanje1 \\
$\mathrm{Sr}$ & $\mathrm{mgL}^{-1}$ & 0.0161 & 0.2543 & 14 & $\mathrm{~N} / \mathrm{A}$ & Mgonanje1 \\
$\mathrm{Zn}$ & $\mathrm{mgL}^{-1}$ & $<\mathrm{DL}$ & 0.069 & 1 & $5^{\mathrm{a}}$ & Afrikana \\
$\mathrm{EC}$ & $\mu \mathrm{S}^{\mathrm{cm}}$ & 166 & 673 & 1 & $1000^{\mathrm{a}}$ & Afrikana \\
$\mathrm{pH}$ & - & 6.46 & 7.27 & 8 & $6.5-8.5^{\mathrm{a}}$ & Maweni \\
$\mathrm{TDS}$ & $\mathrm{mgL}$ & 108 & 431 & 1 & $500^{\mathrm{a}}$ & Afrikana \\
Turbidity & $\mathrm{NTU}$ & 1.16 & 25.6 & 14 & $5^{\mathrm{a}}$ & Mgonanje1 \\
\hline
\end{tabular}

${ }^{\mathbf{a}}$ and ${ }^{\mathbf{b}}$ is according to WHO and USEPA drinking water standards respectively

DL: Detection Limit; MAL: Maximum Admissible Level

Descriptive statistics showing the levels or concentration of the analyzed parameters in water samples are presented in Table-1. The minimum concentrations of some metals are assigned with the mark < DL, indicating theconcentrations were below the detection limit of the ICP-OES. All the raw data are depicted on Figure A1. 


\subsection{Correlation Between Physico-chemical Parameters in the Water Samples}

The correlation among the behavior of analyzed parameters in water samples are expressed by Pearson coefficient. While parameters were observed to have positive correlation, for instance zinc and copper, others correlate negatively for example lead $(\mathrm{Pb})$ and chromium III (Table 2).

Table 2. Correlation between Physico-chemical parameters in the water samples.

\begin{tabular}{|c|c|c|c|c|c|c|c|c|c|c|c|c|}
\hline \multicolumn{13}{|c|}{ Correlation Matrix } \\
\hline Parameters & Cd & Co & $\mathrm{Cr}$ & $\mathrm{Cu}$ & $\mathbf{L i}$ & Mg & $\mathbf{P b}$ & $\mathrm{Sr}$ & $\mathbf{Z n}$ & EC & pH & TDS \\
\hline $\mathrm{Cd}$ & 1 & -0.063 & -0.438 & -0.198 & -0.209 & 0.478 & 0.996 & 0.856 & -0.122 & -0.203 & 0.081 & -0.206 \\
\hline Co & & 1 & 0.132 & -0.030 & -0.286 & -0.289 & -0.051 & -0.228 & 0.092 & -0.488 & -0.504 & -0.492 \\
\hline $\mathrm{Cr}$ & & & 1 & 0.093 & -0.135 & -0.316 & -0.458 & -0.283 & -0.128 & 0.034 & 0.030 & 0.039 \\
\hline $\mathrm{Cu}$ & & & & 1 & 0.299 & 0.308 & -0.193 & -0.026 & 0.845 & 0.559 & -0.083 & 0.561 \\
\hline $\mathrm{Fe}$ & & & & & -0.209 & 0.478 & 0.996 & 0.856 & -0.122 & -0.203 & 0.081 & -0.206 \\
\hline $\mathrm{Li}$ & & & & & 1 & 0.321 & -0.172 & -0.099 & 0.329 & 0.422 & -0.128 & 0.410 \\
\hline $\mathrm{Mg}$ & & & & & & 1 & 0.510 & 0.628 & 0.349 & 0.264 & 0.097 & 0.269 \\
\hline $\mathrm{Ni}$ & & & & & & & 0.990 & 0.857 & -0.122 & -0.202 & 0.081 & -0.204 \\
\hline $\mathrm{Pb}$ & & & & & & & 1 & 0.861 & -0.100 & -0.202 & 0.057 & -0.205 \\
\hline $\mathrm{Sr}$ & & & & & & & & 1 & -0.115 & 0.144 & -0.105 & 0.146 \\
\hline $\mathrm{Zn}$ & & & & & & & & & 1 & 0.240 & -0.052 & 0.242 \\
\hline EC & & & & & & & & & & 1 & 0.083 & 0.999 \\
\hline pH & & & & & & & & & & & 1 & 0.087 \\
\hline TDS & & & & & & & & & & & & 1 \\
\hline
\end{tabular}

\subsection{Levels of pH, EC, TDS and Turbidity in Water Samples}

The values of $\mathrm{pH}, \mathrm{EC}$, TDS, turbidity, as well as metal concentrations are noticeable in Tables 1. Thewater $\mathrm{pH}$ ranged from 6.47 to 7.27 , while the values of EC, TDS, and turbidity (Fig. 3) were evaluated to be 166 to $673 \mu \mathrm{S} / \mathrm{cm}, 108$ to $431 \mathrm{mgL}^{-1}, 1.16$ to $25.6 \mathrm{NTU}$ respectively. The sample areas with maximum levels of the analyzed parameters are marked in Table 1. Strong correlation $\left(\mathrm{r}^{2}=0.999\right)$ was shown between TDS and EC (Fig. 2). The highest level of TDS correlates positively with the highest level of EC ( Table 1).

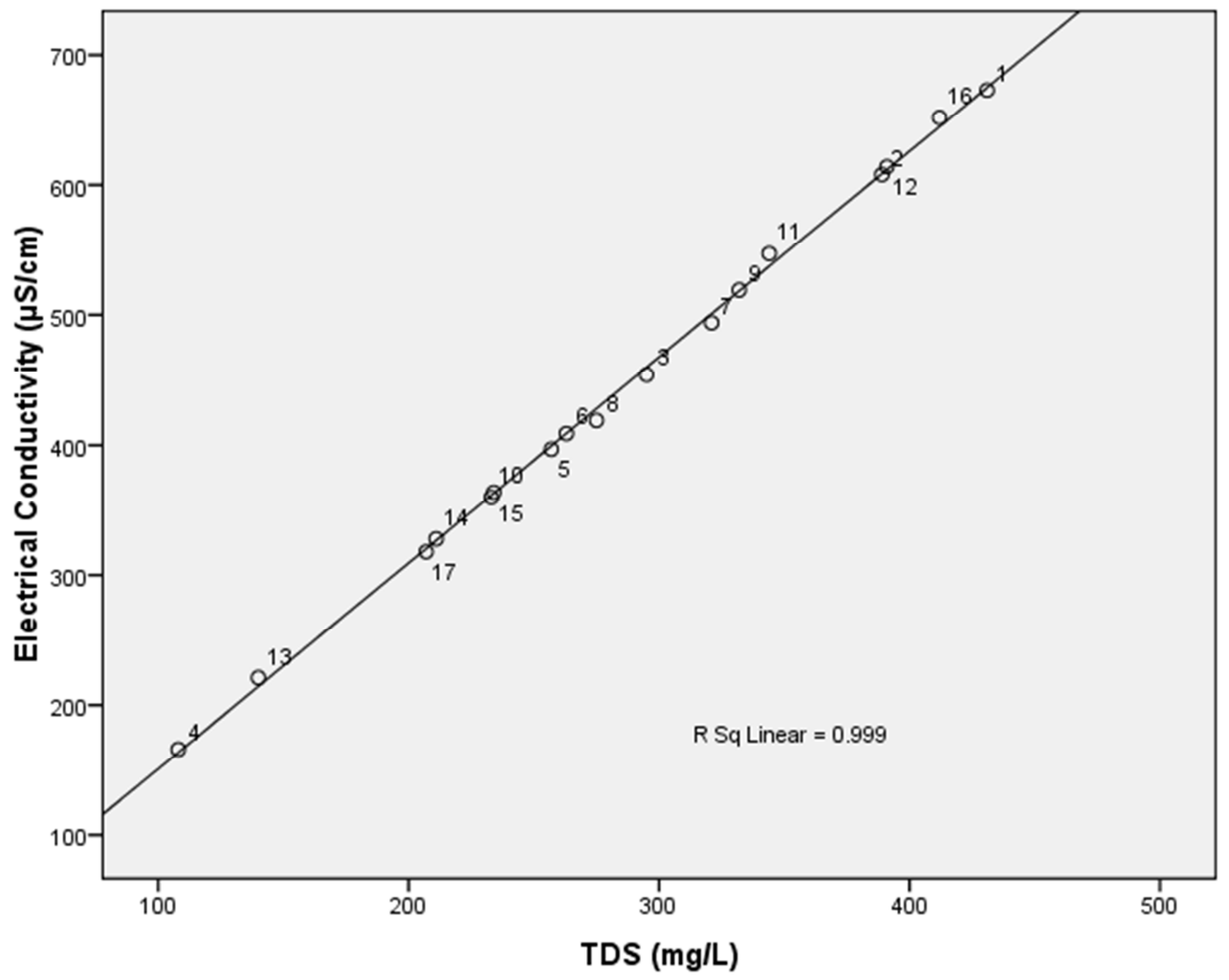

Figure 2. EC-TDS correlation in water samples. 


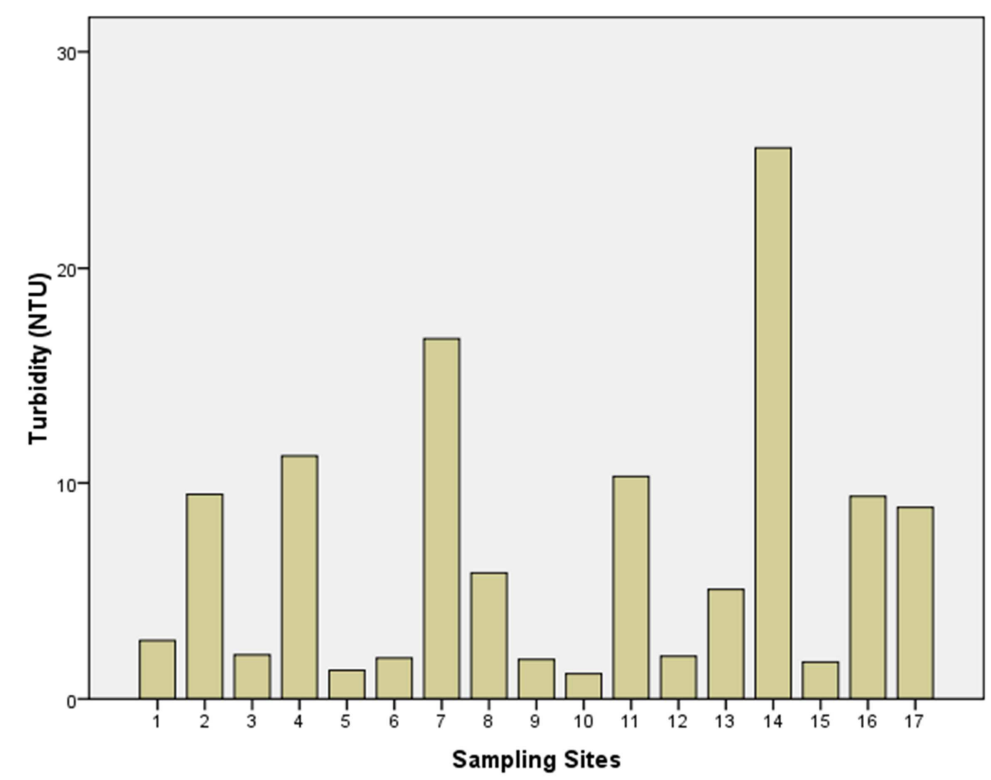

Figure 3. Turbidity levels in water samples.

\subsection{Concentrations of Cr (III), Li, and Sr in Water Samples}

The concentrations of $\mathrm{Cr}$ (III), Li, and $\mathrm{Sr}$ in water samples were in the range of: < DL to $0.0346,0.0162$ to 0.0622 , and 0.0161 to $0.2543 \mathrm{mgL}^{-1}$ respectively (Table-1, Figure 4). As shown on the Figure A1, for $94 \%$ of water samples, lithium to nickel ratios were greater than 1, suggesting relatively higher levels of lithium in analyzed water sources as compared to levels of nickel. In all water samples, strontium to magnesium ratios were less than 1, indicating that strontium is in relatively at higher concentrationsin water sources compared to magnesium.

Strontium showed relatively strong correlation with other metals, such as; $\mathrm{Mg}, \mathrm{Ni}$, and $\mathrm{Pb}$, with Pearson correlation coefficients of $0.628,0.857,0.861$ respectively (Table 2). The strong positive correlation coefficients among analyzed metals may indicate similarities in their physical and chemical properties, and possibly, these metals might originate from common source.

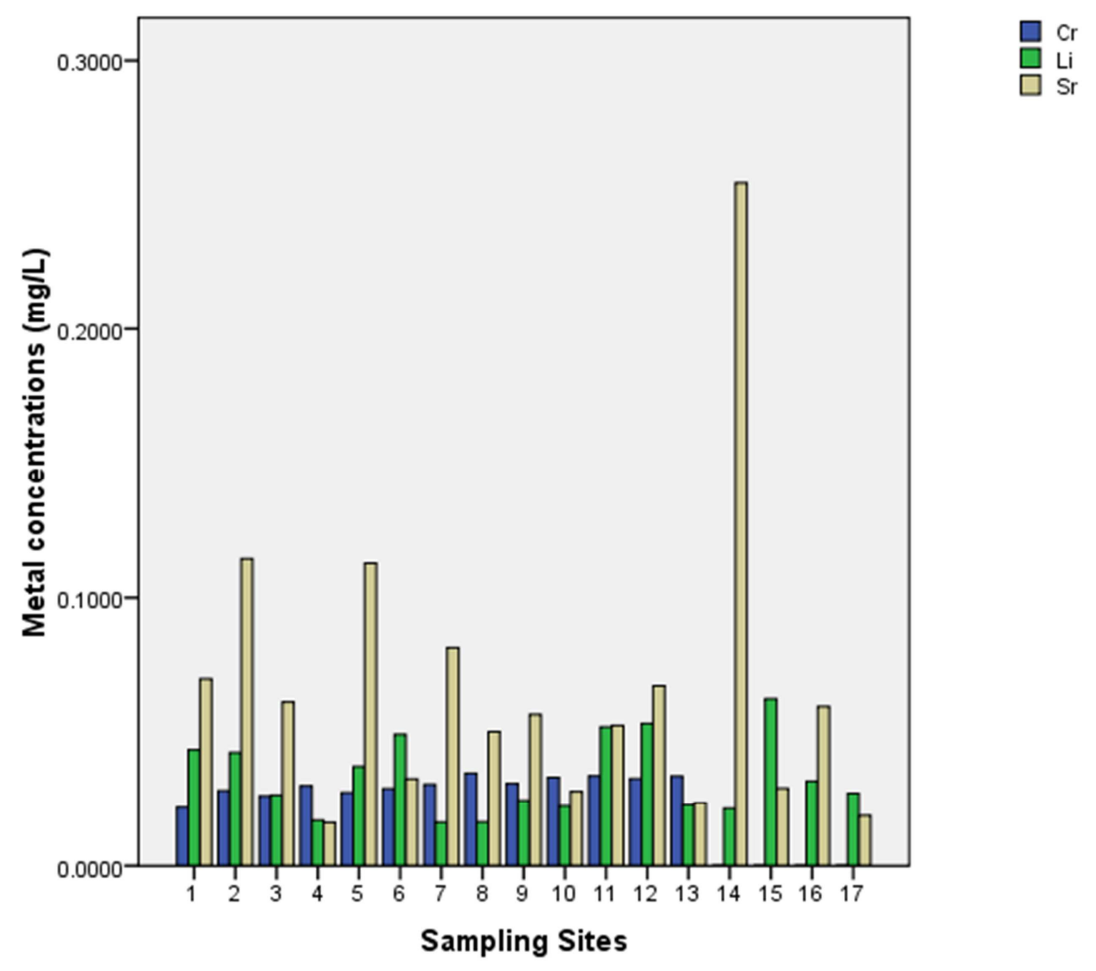

Figure 4. Concentrations of $\mathrm{Cr}$ (III), Li, and Sr in water samples. 


\subsection{Concentrations of Fe and Pbin Water Samples}

The levels of iron $(\mathrm{Fe})$ and lead $(\mathrm{Pb})$ in the samples were in the range of $<$ DL to 0.0057 , and $<$ DL to $0.0097 \mathrm{mgL}^{-1}$ respectively. The highest levels of these parameters were found at Mgonaje1 area (Table 1, Figure 5). Anthropogenic activities are suggested sources for elevated levels of lead and iron at Mgonanje area.

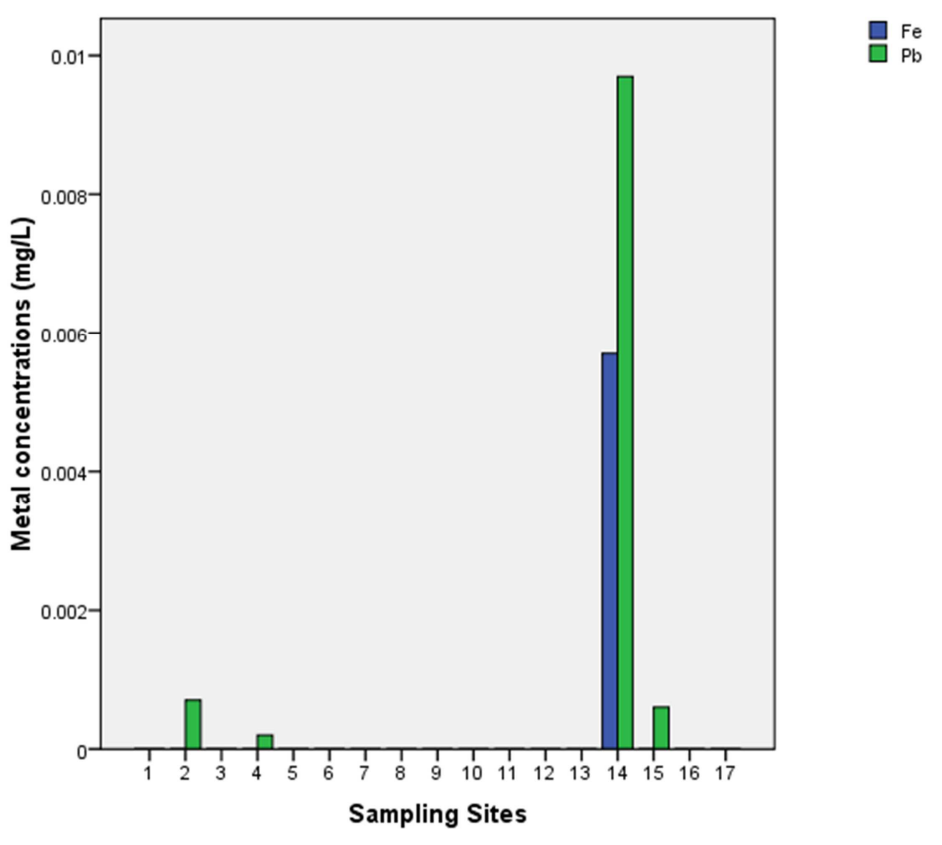

Figure 5. Concentrations of $\mathrm{Fe}$ and $\mathrm{Pb}$ in water samples.

\subsection{Concentrations of $\mathrm{Cu}$ and $\mathrm{Zn}$ in Water Samples}

The concentrations of copper and zinc ranged from $<\mathrm{DL}$ to 0.0612 , and $<\mathrm{DL}$ to $0.069 \mathrm{mgL}^{-1}$ respectively. The maximum levels of copper and zinc were found at Afrikana sampling site (Table 1, Figure 6). Anthropogenic activities, such as the application of fertilizers in agricultural activities are suggested to be the key sources for elevated levels copper and zinc in this area. Copper showed strong correlation with zinc $(r=0.845$, Table 2$)$.

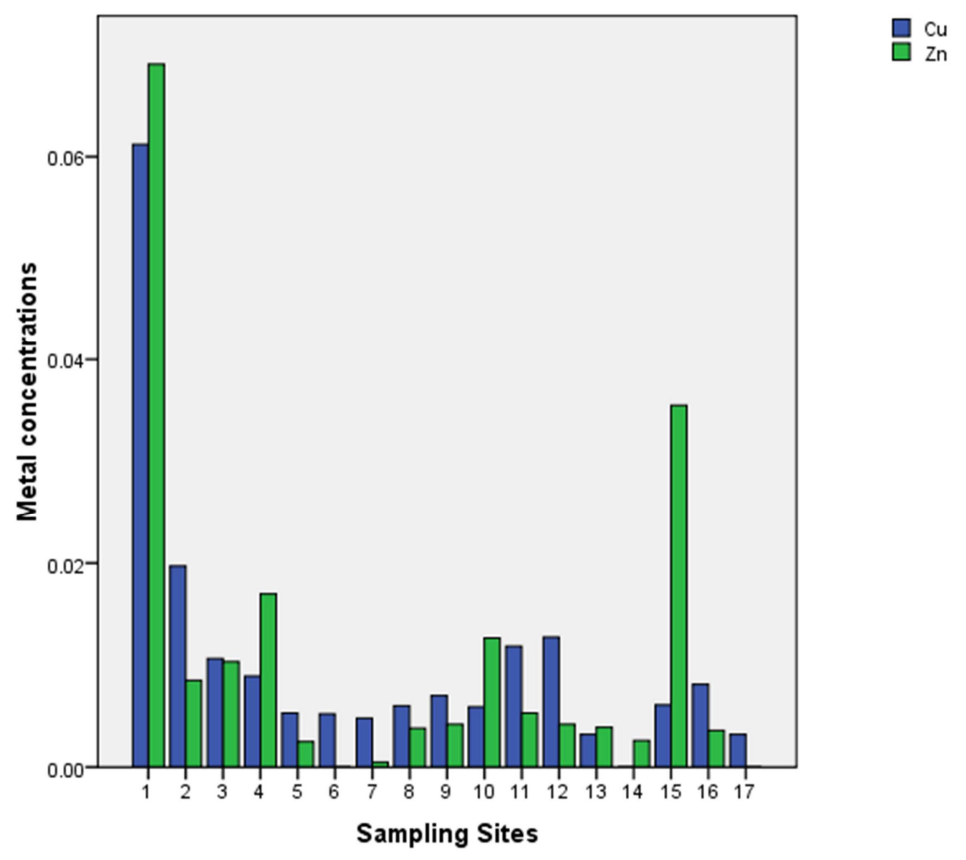

Figure 6. Concentrations of $\mathrm{Cu}$ and $\mathrm{Zn}$ in water samples. 


\subsection{Concentrations of $\mathrm{Cd}$ and $\mathrm{Ni}$ in Water Samples}

The levels of cadmium $(\mathrm{Cd})$ and Nickel $(\mathrm{Ni})$ in the samples were in the range of $<$ DL to 31 , and $<0.0029$ to $10.11 \mathrm{mgL}^{-1}$ respectively. The highest levels of the cadmium and nickel were found at Mgonaje1 area (Table 1,
Figure 7). The difference in levels of the analyzed parameters are affected largely by factors such as polluted domestic effluents, onsiteseptic tanks, the mixing of seawater and freshwater, and heavy metal containing fertilizer applications [9].

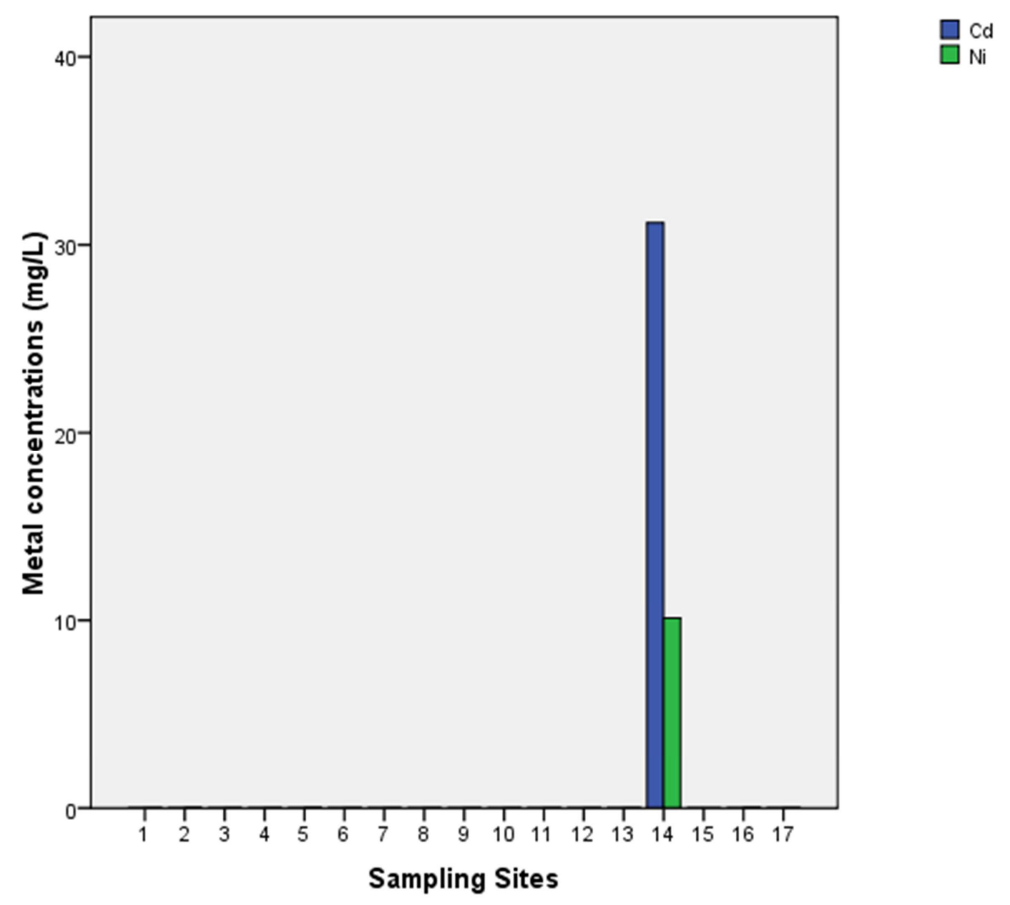

Figure 7. Concentartion of $C d$ and Nickel in water samples.

The concentrations of copper and zinc ranged from 1.2 to Mgonanje1 area (Table 1, Figure 8) $12.3 \mathrm{mgL}^{-1}$. The highest concentration was obtained at

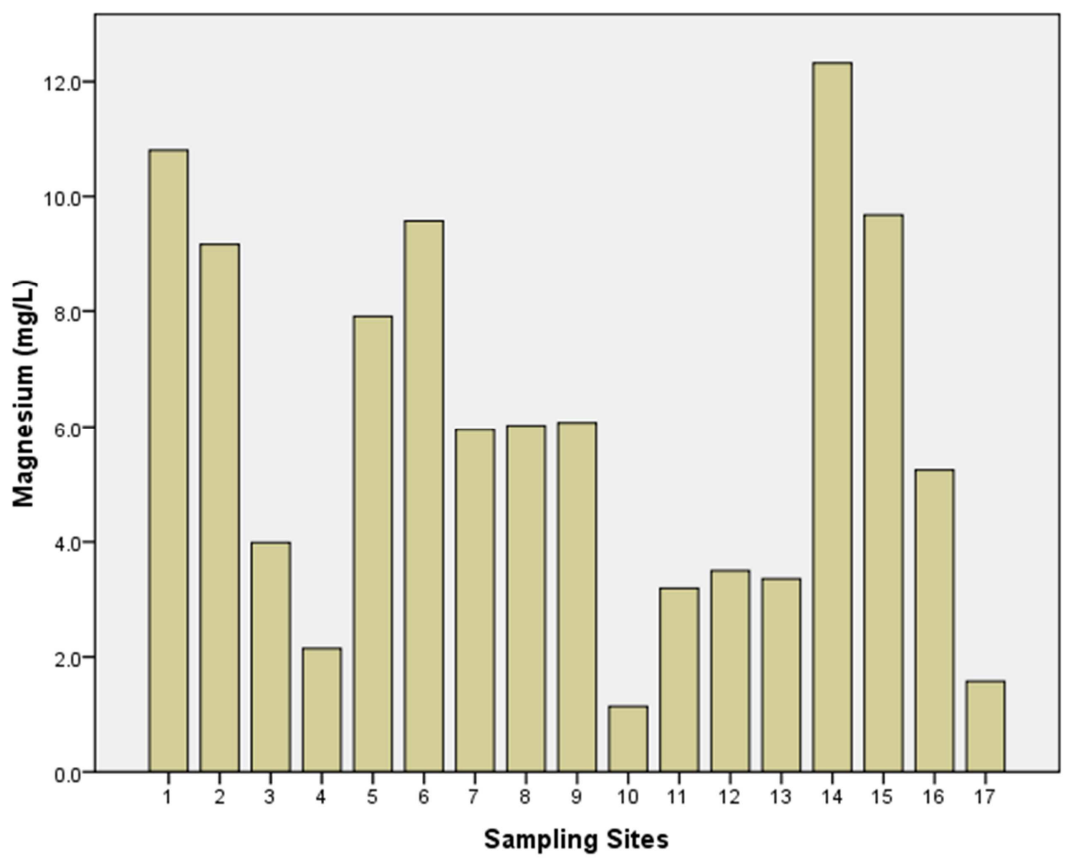

Figure 8. Concentration of $\mathrm{Mg}$ in water samples. 


\section{Conclusion}

The data obtained from the present study reveals that, in comparison to the WHO and or USEPA drinking water standards, all the samples had EC, and TDS within the recommended limits. Greater than fifty percent of the samples had turbidity higher than the WHO recommended values, while greater than quarter of the samples had $\mathrm{pH}$ levels less than the minimum recommended $\mathrm{pH}$ limit. All the samples contained $\mathrm{Co}, \mathrm{Cu}, \mathrm{Fe}, \mathrm{Mg}, \mathrm{Ni}, \mathrm{Pb}$, and $\mathrm{Zn}$ within the maximum admissible limit. However, water sample from Mgonanje-1 had remarkably higher levels of all the three indices, HPI, $\mathrm{C}_{\mathbf{d}}$ and HI. The observed elevated indices at Mgonanje area are suggested to be associated with the use of heavy metal containing fertilizers. This provides an indication of pollution hazards, and absence or weak drinking water treatment practices in the areas, which in turn have vital human health implications. With this regard, the study recommends the stakeholders and other responsible authorities to take appropriate and corrective measures for the water sources, specifically those allocated at Mgonanje and Afrikana. There is a strong demand of introducing relevant drinking water treatment techniques, which can reduce the current levels of contaminants. Prevent any kind of waste disposal near groundwater sources that serve water for domestic and other purposes. Further study should be conducted on other physical, chemical, and biological parameters of significant health concern, and on identification of potential sources of the contaminants. Even though in other areas the values of these three indices are totally below the critical values, yet severe precautions must be given a great consideration because most of the water sources are located down the hills, and or near the paddy fields.

\section{Acknowledgments}

The authors of this manuscript would like to express thanks to His Majesty Government of Brunei Darussalam for funding this project, the State University of Zanzibar for permission for study leave. Special thanks to the staff of the faculty of Science of University Brunei Darussalam for their assistance. To mention few are, Hjh Faridah, Azzlin, Hjh Rasiah, Hj Jamil, Najib, and other UBD chemistry laboratory staffs for providing the necessary facilities and technical support they offer for the successful completion of the project.

\section{Appendix}

$\begin{array}{cccc}\text { Sampling Sites } & 1 & 2 & 3 \\ \mathrm{Cd} & <\mathrm{DL} & <\mathrm{DL} & <\mathrm{DL} \\ \mathrm{Co} & <\mathrm{DL} & <\mathrm{DL} & <\mathrm{DL} \\ \mathrm{Cr} & 0.0218 & 0.0281 & 0.0261 \\ \mathrm{Cu} & 0.0612 & 0.0197 & 0.0107 \\ \mathrm{Fe} & <\mathrm{DL} & <\mathrm{DL} & <\mathrm{DL} \\ \mathrm{Li} & 0.0433 & 0.0423 & 0.0265 \\ \mathrm{Mg} & 10.8 & 9.169 & 3.989 \\ \mathrm{Ni} & 0.0136 & 0.0187 & 0.0106 \\ \mathrm{~Pb} & 0 & 0.0007 & 0 \\ \mathrm{Sr} & 0.0696 & 0.1145 & 0.061 \\ \mathrm{Zn} & 0.069 & 0.0086 & 0.0104 \\ \mathrm{EC} & 673 & 608 & 454 \\ \mathrm{pH} & 7.01 & 6.73 & 6.78 \\ \mathrm{TDS} & 431 & 389 & 295 \\ \text { Turbidity } & 2.69 & 9.48 & 2.03 \\ \text { Li/Ni Ratio } & 3.2 & 2.3 & 2.5 \\ \text { Sr/Mg Ratio } & 0.006 & 0.012 & 0.015 \\ & & & \end{array}$

\begin{tabular}{cc}
4 & \\
$<\mathrm{DL}$ & \\
0.0005 & $<\mathrm{D}$ \\
0.0299 & 0.02 \\
0.009 & 0.00 \\
$<\mathrm{DL}$ & $<\mathrm{D}$ \\
0.017 & 0.03 \\
2.146 & 7.9 \\
0.0057 & 0.018 \\
0.0002 & \\
0.0161 & 0.11 \\
0.017 & 0.002 \\
166 & \\
6.49 & \\
108 & 6.4 \\
11.3 & 1.32 \\
3.0 & 2.0 \\
0.008 & 0.01 \\
\hline
\end{tabular}

\begin{tabular}{cc}
5 & \\
$<\mathrm{DL}$ & $<\mathrm{DL}$ \\
$<\mathrm{DL}$ & $<\mathrm{DL}$ \\
0.0274 & 0.0289 \\
0.0053 & 0.0052 \\
$<\mathrm{DL}$ & $<\mathrm{DL}$ \\
0.0371 & 0.049 \\
7.91 & 9.574 \\
0.0186 & 0.0062 \\
$<\mathrm{DL}$ & $<\mathrm{DL}$ \\
0.1128 & 0.0325 \\
0.0025 & $<\mathrm{D}$ \\
397 & 409 \\
6.46 & 7.17 \\
257 & 263 \\
1.32 & 1.88 \\
2.0 & 7.9 \\
0.014 & 0.003 \\
\hline
\end{tabular}

\begin{tabular}{|c|c|}
\hline 6 & 7 \\
\hline$<\mathrm{DL}$ & $<\mathrm{DL}$ \\
\hline$<D L$ & $<\mathrm{DL}$ \\
\hline 0.0289 & 0.0304 \\
\hline 0.0052 & 0.0048 \\
\hline$<\mathrm{DL}$ & $<D L$ \\
\hline 0.049 & 0.0162 \\
\hline 9.574 & 5.95 \\
\hline 0.0062 & 0.0141 \\
\hline$<D L$ & $<D L$ \\
\hline 0.0325 & 0.0811 \\
\hline$<\mathrm{DL}$ & 0.0005 \\
\hline 409 & 494 \\
\hline 7.17 & 7.13 \\
\hline 263 & 321 \\
\hline 1.88 & 16.7 \\
\hline 7.9 & 1.1 \\
\hline 0.003 & 0.014 \\
\hline
\end{tabular}

\begin{tabular}{cc}
8 & 9 \\
$<\mathrm{DL}$ & $<\mathrm{D}$ \\
$<\mathrm{DL}$ & $<\mathrm{DL}$ \\
0.0346 & 0.0307 \\
0.006 & 0.007 \\
$<\mathrm{DL}$ & $<\mathrm{DL}$ \\
0.0163 & 0.0244 \\
6.024 & 6.075 \\
0.007 & 0.009 \\
$<\mathrm{DL}$ & $<\mathrm{D}$ \\
0.05 & 0.0564 \\
0.0038 & 0.0042 \\
419 & 519 \\
7.27 & 7.26 \\
275 & 332 \\
5.85 & 1.82 \\
2.3 & 2.5 \\
0.008 & 0.009 \\
\hline
\end{tabular}

$\begin{array}{cc}9 & 10 \\ <\mathrm{DL} & <\mathrm{D} \\ <\mathrm{DL} & <\mathrm{D} \\ 0.0307 & 0.033 \\ 0.007 & 0.00 \\ <\mathrm{DL} & <\mathrm{D} \\ 0.0244 & 0.02 \\ 6.075 & 1.15 \\ 0.0096 & 0.006 \\ <\mathrm{DL} & <\mathrm{D} \\ 0.0564 & 0.02 \\ 0.0042 & 0.0127 \\ 519 & 360 \\ 7.26 & 7.08 \\ 332 & 233 \\ 1.82 & 1.16 \\ 2.5 & 3.4 \\ 0.009 & 0.024 \\ & \end{array}$

\begin{tabular}{|c|c|c|}
\hline 10 & 11 & 12 \\
\hline$<\mathrm{DL}$ & $<D L$ & $<D L$ \\
\hline$<D L$ & $<D L$ & $<D L$ \\
\hline 0.033 & 0.0336 & 0.0326 \\
\hline .0059 & 0.0119 & 0.0128 \\
\hline$<\mathrm{DL}$ & $<\mathrm{DL}$ & $<\mathrm{DL}$ \\
\hline .0223 & 0.0518 & 0.0531 \\
\hline 1.15 & 3.179 & 3.503 \\
\hline .0065 & 0.0116 & 0.0115 \\
\hline$<\mathrm{DL}$ & $<\mathrm{DL}$ & $<D L$ \\
\hline 0.0278 & 0.0523 & 0.067 \\
\hline .0127 & 0.0053 & 0.0042 \\
\hline 360 & 547 & 614 \\
\hline 7.08 & 6.82 & 7 \\
\hline 233 & 344 & 391 \\
\hline 1.16 & 10.3 & 1.97 \\
\hline 3.4 & 4.5 & 4.6 \\
\hline 0.024 & 0.016 & 0.019 \\
\hline
\end{tabular}

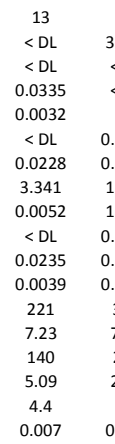

$\begin{array}{cccc}14 & 15 & 16 & 17 \\ 31.16 & <\mathrm{DL} & <\mathrm{DL} & <\mathrm{DL} \\ <\mathrm{DL} & <\mathrm{DL} & <\mathrm{DL} & <\mathrm{DL} \\ <\mathrm{DL} & <\mathrm{DL} & <\mathrm{DL} & <\mathrm{DL} \\ 0 & 0.0061 & 0.0082 & 0.0032 \\ 0.0057 & <\mathrm{DL} & <\mathrm{DL} & <\mathrm{DL} \\ 0.0214 & 0.0622 & 0.0316 & 0.0271 \\ 12.32 & 9.68 & 5.242 & 1.58 \\ 10.11 & 0.0029 & 0.0193 & 0.0062 \\ 0.0097 & 0.0006 & <\mathrm{DL} & <\mathrm{DL} \\ 0.2543 & 0.029 & 0.0593 & 0.0187 \\ 0.0026 & 0.0355 & 0.0036 & <\mathrm{DL} \\ 328 & 364 & 652 & 318 \\ 7.04 & 7.02 & 6.94 & 6.95 \\ 211 & 234 & 412 & 207 \\ 25.6 & 1.7 & 9.39 & 8.88 \\ 0.0 & 21.4 & 1.6 & 4.4 \\ 0.021 & 0.003 & 0.011 & 0.012\end{array}$

Figure A1. Raw data of physico-chemical parameters in water samples.

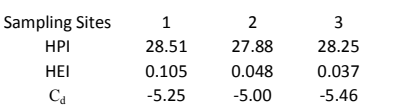

$\begin{array}{llll}\mathrm{HEI} & 0.105 & 0.048 & 0.037 \\ \mathrm{C}_{\mathrm{d}} & -5.25 & -5.00 & -5.46\end{array}$

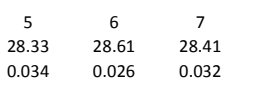

$\begin{array}{lll}0.034 & 0.026 & 0.032 \\ -5.06 & -5.68 & -5.29\end{array}$

Figure A2. Metal Pollution indices.

$\begin{array}{ccccccccc}9 & 10 & 11 & 12 & 13 & 14 & 15 & 16 & 17 \\ 28.38 & 28.24 & 28.15 & 28.18 & 28.49 & 858.01 & 28.73 & 28.80 & 29.24 \\ 0.033 & 0.037 & 0.040 & 0.039 & 0.029 & 4.184 & 0.029 & 0.020 & 0.006 \\ -5.51 & -5.67 & -5.41 & -5.41 & -5.74 & 10886.84 & -5.80 & -5.03 & -5.69\end{array}$

[4] Agbaire PO, Oyibo IP (2009) Seasonal variation of some physico- chemical properties of borehole water in Abraka, Nigeria. Afr. J. Pure Appl. Chem., 3: 116-118.

[5] Srinivasamoorthy K, Nanthakumar C, Vasanthavigar M., Vijayaraghavan K, Rajivgandhi, R., et al. (2009) Groundwater quality assessment from a hard rock terrain, Salem district of Tamilnadu, India, Arabian J. Geosci., DOI=10.1007/s125170-09-0076-7.

[6] WHO (2003) Quantifying selected major risks to health, The World Health Report 2002, World Health Organization, Geneva.

[7] Suthar S, Chhimpa V, Singh S (2008) Bacterial contamination in drinking water: a case study in rural areas of northern Rajasthan, India. Environ Monit Asses, DOI 10.1007/s10661008-0611-0. 
[8] Phansalkar S J, Kher V, Deshpande P (2005) Expanding Rings of Dryness: Water Imports from Hinterlands to Cities and the Rising Demands of Mega-Cities, in IWMI-Tata Annual Partner's Meet, Anand.

[9] Mohamed AAJ, Abdul Rahman I, Lim LH (2014a) Groundwater quality assessment in the urban-west region of Zanzibar Island, EnvironMonit Assess., 186: 6287-6300.

[10] Mohamed AAJ, Abdul Rahman I, Said SA, Lim LH (2014b) Occurrence of Arsenic, Lead, Thallium and Beryllium in Groundwater, American J. Env. Sci., 10: 164-170.

[11] Helios-Rybicka E, Adamiec E, Aleksander-Kwaterczak U (2005) Distribution of trace metals in the Odra River system: Water-suspended matter-sediments, Limnologica, 35: 185189.

[12] Sarala C, Ravi BP (2012) Assessment of Groundwater Quality Parameters in and around Jawaharnagar Hyderabad, Int. J. Sci., 2: 1-6.

[13] Milenkovic N, Damjanovic M, Ristic M (2005) Study of heavy metal pollution in sediments from the Iron Gate (Danuae River), Serbia and Montenegro. Polish J. Env. Study, 14: 781-787.

[14] Bellinger DC (2008) Very low lead exposures and children's neurodevelopment. Current opinion in pediatrics, 20: 172177.

[15] Perronnet K, Schwartz C, Gerard E, Morel JL, (2000) Availability of cadmium and zinc accumulated in the leaves of Thlaspicaerulescens incorporated into soil. Plant Soil, 227: 257-263.
[16] Rajappa B, Manjappa S, Puttaiah ET (2010) Monitoring of heavy metal concentration in groundwater of Hakinaka Taluk, India. Contemporary Eng. Sci., 3: 183-190.

[17] Nriagu JO (1988) A silent epidemic of environmental metal poisoning? Envir. Pollution, 50: 139-161.

[18] Tuzen M, Soylak M (2006) Evaluation of metal levels of drinking waters from the Tokat-black sea region of Turkey, Polish J. Env. Study, 15: 915-919.

[19] Thomas KB, Francis O, Samuel OA, Osei A (2015) Pollution evaluation, sources and risk assessment of heavy metals in hand-dug wells from Ejisu-Juaben Municipality, Ghana Environ Syst. Res. 4: 18.

[20] Prasad B, Bose JM (2001) Evaluation of heavy metal pollution index for surface and spring water near a limestone mining area of the lower Himalayas, Envir. Geology, 41: 183188.

[21] Backman B, Bodis D, Lahermo P, Rapant S (1997) Application of a groundwater contamination index in Finland and Slovakia. Envir. Geology, 36: 55-64.

[22] Rubio B, Nombela MA, Vilas F ( 2000) Geochemistry of Major and Trace Elements in Sediments of the Ria de Vigo (NW Spain): an Assessment of Metal Pollution. Marine Pollution Bulletin, 40: 968-980.

[23] Edet AE, Offiong OE (2002) Evaluation of water quality pollution indices for heavy metal contamination monitoring. A study case from Akpabuyo - Odukpani area, Lower Cross River Basin, (southeastern Nigeria), Geo J. 57: 295-304. 